\title{
Pola Pemberitaan Media Online Kompas.com dalam Pelaporan Serangan Terorisme di Indonesia 2016-2020
}

\author{
Asri Pangestu dan Sukma Ari Ragil Putri \\ Fakultas Ushuluddin, Adab dan Dakwah, UIN Sayyid Ali Rahmatullah Tulungagung \\ asrri.pangestu@gmail.com
}

\begin{abstract}
Since 2016, the number of terrorist attacks in Indonesia has increased. As a result, these incidents attracted media attention and received extensive coverage. This study aims to examine the role of online news media Kompas.com in reporting terrorism attacks during 2016-2020, because online news media have taken over print and television media as the most popular news sources, thus enabling them to reach and influence the largest audience. This research approach has a qualitative perspective using the method of content analysis. The data obtained for this study was accessed and collected through the online news site Kompas.com in the period 2016-2020 referring to the highest number of articles covering terrorist attacks. The data analysis used in this research is the interpretive thematic analysis technique from Braun \& Clarke. This research is based on the Agenda Setting Theory. Research reveals that news coverage of terrorist attacks in Indonesia includes facts about the perpetrators, solidarity between communities, emotional quotes about the suffering of victims, and descriptions of violence. The results showed that the online news media Kompas.com through its reporting about the perpetrators created terrorist stereotypes. Then by describing the suffering of the victims, Kompas.com mediates various emotional effects in the community. In addition, a focus on violence in reporting can spread fear and panic among the public. Interestingly, the online news media Kompas.com acts as an advocate of solidarity and can even encourage the community to support the victims and their families both financially and psychologically.
\end{abstract}

Keywords: terrorism; online news; Kompas.com; ISIS; pattern

\begin{abstract}
Abstrak
Sejak 2016, jumlah serangan teroris di Indonesia telah meningkat. Akibatnya, insideninsiden ini begitu menarik perhatian media dan banyak mendapatkan liputan. Penelitian ini bertujuan mengkaji peran media berita online Kompas.com dalam pemberitaan serangan terorisme selama 2016-2020, karena media berita online telah mengambil alih media cetak dan televisi sebagai sumber pemberitaan terpopuler, sehingga memungkinkannya menjangkau dan memengaruhi khalayak terbanyak. Pendekatan penelitian ini berperspektif kualitatif dengan menggunakan metode analisis isi. Data yang didapat untuk penelitian ini diakses dan dikumpulkan melalui situs berita online Kompas.com dalam kurun waktu tahun 2016-2020 mengacu pada jumlah artikel liputan serangan teroris tertinggi. Analisis data yang digunakan dalam penelitian ini adalah teknik analisis tematik dari Braun dan Clarke. Penelitian ini didasarkan pada teori Penyusunan Agenda. Penelitian mengungkapkan bahwa liputan berita serangan teroris di Indonesia mencakup berbagai fakta tentang pelaku, solidaritas antar masyarakat, kutipan emosional tentang penderitaan para korban, dan deskripsi kekerasan. Hasil penelitian menunjukkan bahwa media berita online Kompas.com melalui pemberitaannya tentang pelaku menciptakan stereotip teroris. Lalu melalui penggambaran penderitaan para korban, Kompas.com memediasi berbagai efek emosional di kalangan masyarakat. Selain itu, fokus pada kekerasan dalam pemberitaan dapat menebar ketakutan dan kepanikan di kalangan publik. Menariknya lagi bahwa media berita online Kompas.com berperan sebagai penggerak solidaritas dan bahkan dapat mendorong masyarakat untuk mendukung para korban dan keluarganya baik secara finansial maupun psikologis.
\end{abstract}

Kata kunci: terorisme; berita online; Kompas.com; ISIS; pola

Korespondensi: Asri Pangestu, S.Sos., Fakultas Ushuluddin, Adab dan Dakwah Universitas Islam Negeri Sayyid Ali Rahmatullah, Jl. Mayor Sujadi Timur No.46, Kec. Kedungwaru, Kab. Tulungagung, Jawa Timur 66221, Email: asrri.pangestu@gmail.com

Menyerahkan: Juli 2021, Diterima: Januari 2022, Terbit: Januari 2022

ISSN: 2549-0559 (cetak), ISSN: 2549-1946 (online), Website: http://jurnal.unpad.ac.id/kajian-jurnalisme 
194 | Kajian Jurnalisme

Volume 05 Nomor 02 Tahun 2022

DOI: $10.24198 / \mathrm{jkj} . v 5 \mathrm{i} 2.34429$

\section{PENDAHULUAN}

Teror bom di kawasan Sarinah, ledakan bom di Kampung Melayu, bom di tiga gereja Surabaya dan sederet serangan terorisme lain di negeri ini menjadi bukti bahwa terorisme menjadi masalah besar di Indonesia (Junaedi, 2017), serta Indonesia dinilai sedang menghadapi darurat terorisme (Pabyantara, Wibowo, \& Zamzamy, 2018). Tercatat dari 2016 ketika serangan teroris mulai meningkat, serangan-serangan ini telah banyak menerima perhatian media. Fenomena tersebut telah menjadi topik yang sangat hangat dalam berita bagi masyarakat Indonesia selama beberapa tahun terakhir.

Sebagai negara mayoritas umat Islam terbesar di dunia, Indonesia diketahui menjadi salah satu negara yang didiami oleh kelompok teroris (Windiani, 2018). Bahkan Bakti (2014) menyebutkan bahwa dunia internasional menilai Indonesia sebagai negara 'sarang' terorisme. Kelompok teroris ini didasarkan pada ekstrimisme agama, khususnya agama Islam. Mereka menuntut tegaknya syariat Islam (Purwawidada, 2014). Berupaya mendirikan ke-khalifahan, bentuk Daulah Islamiyah di Indonesia (Dermawan, Affandi, \& Alam, 2018) dengan melakukan aksi pemboman fasilitas publik, simbol-simbol agama dan negara, dan eksekusi publik (Djelantik, 2010). Tujuan utama di balik setiap serangan teroris adalah perhatian media yang ingin dicapai oleh pelaku untuk menyebarkan ideologinya (Djelantik, 2010).

Sasaran utama para pelaku terorisme adalah orang-orang dengan respon emosional dan yang menaruh perhatian mendalam pasca serangan teroris yang menyebabkan kerusakan, jumlah korban luka dan mati yang tinggi (Djelantik, 2010). Andi Widjajantodermawan selaku Analis Utama Politik keamanan LAB 45 melalui Kompas.com 30 Maret 2021 menyebutkan, telah tercatat 552 aksi teror di Indonesia dari tahun 2000-2021 dan kelompok teroris ini telah menyebabkan beberapa serangan fatal di beberapa titik daerah di Indonesia (Farisa, 2021). Akibatnya, serangan-serangan ini telah menerima banyak perhatian media dan mendominasi pemberitaan nasional.

Tuntutan untuk terus beradaptasi di tengah melesatnya gempuran media digital dan menurunnya tiras surat kabar, membuat konsep media berita online telah banyak dibicarakan akhir-akhir ini, karena telah menjadi sumber berita utama bagi masyarakat Indonesia (Handayani \& Merdekawati, 2019). Situs berita online hadir di tengah minimnya peminat berita dalam media cetak dan media elektronik, seperti; radio dan televisi (Musyaffa, 2017). Akses internet yang mudah telah mengubah media berita online menjadi cara yang cepat dan informatif bagi masyarakat untuk mengakses pemberitaan. Kemampuan media berita online untuk terus memberikan informasi yang masif kepada masyarakat dan menjangkau jumlah pengunjung yang tinggi, meningkatkan pula pengaruhnya terhadap masyarakat. Atas meningkatnya pengaruh tersebut secara bersamaan memberdayakan peran yang dimainkan media berita online dalam melaporkan serangan terorisme.

Portal berita terkemuka di Indonesia Kompas.com memberikan kesempatan kepada publik untuk mengakses berita secara online dari situs Kompas.com. Berdasarkan hasil survey Roy Morgan yang dilakukan pada April 2017 sampai dengan Mei 2018, Kompas.com menerima jumlah pengunjung kedua tertinggi dari semua situs berita di Indonesia. Lebih dari 7,3 juta orang dalam periode rata-rata empat minggu (Roy Morgan, 2018). Menjadikan Kompas.com memainkan peran penting saat melaporkan serangan terorisme. Kompas.com menjadi portal berita online yang selektif dalam menyajikan suatu pemberitaan terkait peristiwa serangan terorisme, terangkum dalam liputan khusus (lipsus) yang di antaranya; Teror Di Kawasan Sarinah (2016) yang memiliki 250 artikel, Ledakan Bom Di Kampung Melayu (2017) 207 artikel, dan Bom Di Gereja Surabaya (2018) 237 artikel yang memungkinkan pembaca mendapatkan informasi yang mendalam, terstruktur dan detail setiap kejadian. Lebih lanjut, 
dibandingkan dengan liputan serangan terorisme lainnya dalam kurun waktu 2016-2020, masing-masing peristiwa liputan khusus tersebut memiliki jumlah artikel paling banyak. Karena alasan tersebut dan popularitas situs berita, artikel liputan Kompas.com diteliti dengan melakukan analisis tematik terhadap artikel berita dalam penelitian ini.

Penelitian ini didasarkan pada teori Penyusunan Agenda (selanjutnya disebut teori Agenda Setting) untuk mengetahui tema pemberitaan seperti apa yang dibentuk oleh media khususnya media berita online Kompas.com sehingga memiliki efek pada sikap kognitif dan afektif masyarakat. Dengan kata lain, teori Agenda Setting menganggap media memiliki kekuatan untuk menarik perhatian dan memengaruhi masyarakat terhadap suatu isu. Asumsinya, media massa memiliki kekuatan untuk membentuk pikiran masyarakat mengenai isu-isu apa yang sebaiknya dianggap penting, atau dalam kasus ini tema apa yang dianggap paling penting ditonjolkan dalam pemberitaan mengenai terorisme (Rahmat, 1993).

Lebih lanjut lagi, Mc Combs dan Donald Shaw (Martha \& Irwansyah, 2017) mengemukakan bahwa apa yang dianggap penting bagi media maka dianggap penting juga oleh publik. Karena itu jika media massa memberikan perhatian pada berita tertentu dan mengabaikan lainnya maka akan memiliki efek pada pendapat masyarakat terhadap suatu isu. Proses kerja dari Agenda Setting sendiri terdiri dari beberapa tahapan. Pertama, agenda media dalam menentukan prioritas isu yang ada. Kedua, agenda publik yaitu ketika isu dapat mengubah kognisi masyarakat. Ketiga, agenda kebijaksanaan yaitu ketika pembuat kebijakan menganggap penting agenda publik yang telah dibentuk oleh media. Sehingga jika kemudian dirunut, maka agenda media dapat menjadi bagian dari ideologi agenda kebijakan pemerintah (Effendy, 2009).

Hubungan antara media dan terorisme selama ini telah banyak dibicarakan oleh peneliti dan disebut sebagai simbiosis karena saling menguntungkan (Djelantik, 2010). Namun, dalam simbiosis ini, belum banyak perhatian yang diberikan terutama pada peran media berita online. Meskipun dikatakan bahwa liputan media tentang terorisme dapat memprovokasi berbagai emosi di kalangan masyarakat, bahkan mendorong terjadinya serangan lebih lanjut (Dewan Pers, 2017), sejauh ini mayoritas penelitian difokuskan terutama pada pengaruh media massa secara keseluruhan. Pola pemberitaan media berita online saat memberitakan serangan terorisme di Indonesia belum cukup diperhatikan, karena belum ada penelitian yang secara langsung menanganinya. Oleh karena itu, untuk mengetahui pola tersebut, penelitian ini mengkaji pola pemberitaan media berita online dalam memberitakan serangan terorisme dengan menggunakan artikel liputan nyata dari Kompas.com.

\section{METODE}

Penelitian ini berperspektif kualitatif dengan menggunakan pendekatan analisis isi. Sifat penelitian ini adalah deskriptif analisis yang bertujuan untuk mendeskripsikan karakteristik pemberitaan serangan terorisme di Kompas.com. Selanjutnya, metode analisis tematik digunakan untuk menentukan pola tematik dalam data. Analisis tematik memberi peneliti kesempatan untuk menganalisis dan menyelidiki berbagai topik dalam perspektif yang dalam dan luas (Jonathan \& Herdiana, 2020). Braun dan Clarke (2006) mengatakan ada enam tahap dalam melakukan anlisis tematik, di antaranya; mengenal data yang akan dianalisis, menghasilkan kode awal, menyelidiki tema, menuju tema turunan, mendefinisikan tema akhir, dan merepresentasikan analisis akhir. Analisis tematik ini dianggap sebagai yang paling berpengaruh (Heriyanto, 2018), maka digunakan untuk penelitian ini.

Selama melakukan analisis, semua artikel diberi kode khusus agar lebih mudah merujuk dan mengutip saat peneliti memeriksa data dan menyajikan temuan. Kode-kode tersebut 
196 | Kajian Jurnalisme

Volume 05 Nomor 02 Tahun 2022

DOI: $10.24198 / \mathrm{jkj} . v 5 \mathrm{i} 2.34429$

dikembangkan selama proses melakukan analisis artikel berita. Setiap artikel dikutip, kode ditulis di sebelah kutipan. Dengan demikian, pengkodean terbuka (open coding) (Budiasih, 2014) digunakan di saat melakukan analisis.

Data yang didapat untuk penelitian ini diakses dan dikumpulkan melalui situs berita online Kompas.com. Data berupa artikel serangan terorisme di Indonesia yang dikumpulkan dalam kurun waktu tahun 2016 hingga 2020 mengacu pada jumlah tertinggi artikel liputan media. Data penelitian dikumpulkan secara manual sambil memasukkan kata kunci ke mesin pencari google, seperti terorisme, ledakan bom, serangan bom bunuh diri, Kompas.com, dan lain-lain.

\section{HASIL DAN PEMBAHASAN}

Peran media berita online Kompas.com dalam memberitakan serangan terorisme di Indonesia dalam kurun waktu lima tahun terakhir (2016-2020) menjadi subjek yang penting yang akan diselidiki karena kurangnya informasi di lapangan dan relevansinya pemerintah dalam misi memberantas terorisme. Maka dari itu, analisis Kompas.com meliputi berita dari Januari 2016 semenjak terjadinya bom Sarinah hingga Agustus 2020 telah dilakukan, yang pada akhirnya merepresentasikan beberapa temuan berharga untuk dibahas secara rinci. Empat tema utama dengan sub-tema dari hasil data ditemukan saat melakukan analisis tematik. Tema utamanya adalah: 'pelaku', 'solidaritas', 'korban', dan 'kekerasan'.

Tabel 1. Tema dan Sub-tema Penelitian

\begin{tabular}{|c|c|c|}
\hline No & Tema & Sub-tema \\
\hline \multirow{3}{*}{1} & \multirow{3}{*}{ Pelaku } & Latar Belakang Psikologis \\
\hline & & Catatan Kepolisian \\
\hline & & Tautan dengan ISIS \\
\hline \multirow{3}{*}{2} & \multirow{3}{*}{ Solidaritas } & Penggalangan Dana \\
\hline & & Optimisme Masyarakat \\
\hline & & Dukungan dari Influencer \\
\hline \multirow{3}{*}{3} & \multirow{3}{*}{ Korban } & Upacara Pemakaman \\
\hline & & Kehilangan Keluarga \\
\hline & & Penghormatan bagi Korban \\
\hline \multirow{3}{*}{4} & \multirow{3}{*}{ Kekerasan } & Cedera \\
\hline & & Deskripsi Adegan \\
\hline & & Peningkatan Tingkat Ancaman \\
\hline
\end{tabular}

Sumber: diolah dari: Kompas.com (2016-2020)

\section{Tema 1: Pelaku}

Dalam artikel berita, pelaku banyak dibahas sebagai subjek yang diidentifikasikan sebagai 'pembom'. Sebagai subjek, pelaku ditampilkan sebagai pribadi dengan latar belakang psikologis, catatan kegiatan tertentu pelaku oleh kepolisian, dan juga digambarkan mempunyai keterkaitan dengan ISIS. Representasi pelaku di artikel berita memunculkan citra stereotip dari pelaku dan memberikan latar belakang pengetahuan kepada masyarakat tentang ISIS. Penggambaran 'latar belakang psikologis', 'catatan kepolisian', dan 'tautan dengan ISIS' dimunculkan sebagai kategori pelaku:

Latar Belakang Psikologis. Sambil menyajikan gambaran umum pelaku, media berita 
online Kompas.com juga mengidentifikasikan ciri-ciri kepribadian pelaku aksi teror tersebut. Dengan cara ini liputan media merangsang gagasan kepada pembaca tentang ciri-ciri kepribadian pelaku seorang terorisme *:

"Guru Besar Kriminologi Pascasarjana UI Tubagus Ronny R.N mengatakan: Bahrun Naim yang merupakan anggota ISIS yang diduga menjadi dalang aksi teror di Jalan MH Thamrin, pekan lalu. Dilihat dari jarak mata kiri dan kanan, wajahnya itu tidak simetris. *Saya lihat dari wajahnya Bahrun Naim bahwa tidak toleran dengan orang lain dan mudah merasa terganggu dengan hal-hal kecil." (Kompas.com, 21/01/2016) KOMPAS14:Hal.7-No.4

"Guru Besar Kriminologi Pascasarjana UI Tubagus Ronny R.N mendeskripsikan kepribadian Afif: Dari rahang dagunya, dia ciri-ciri yang memiliki percaya diri yang tinggi. Rupanya itu, dia memang lebih fokus pada jihadnya bahwa, menurut dia, *orang di luar dia kafir semua. Jadi, perkembangan jiwanya yang berfungsi membedakan mana baik dan salah, itu dirasuki oleh paham yang salah. Makanya, *dia gandrung akan kematian." (Kompas.com, 21/01/2016) KOMPAS15:Hal.7-No.5

Selain itu, media berita online Kompas.com juga menggambarkan pelaku sebagai seseorang yang enggan bersosial dengan tetangganya. Pelaku direpresentasikan sebagai individu yang pendiam dan memisahkan dirinya dari masyarakat:

"Ia tidak habis pikir bahwa tetangganya itu bisa terlibat aksi teror tersebut. Sebab, dalam kesehariannya, MA dikenal sebagai orang yang pendiam. Haripah mengatakan bahwa MA *tidak banyak bergaul dengan para tetangga, demikian juga istrinya, MS." (Kompas.com, 16/01/2016) KOMPAS29:Hal.19-No.2

"Kabid Humas Polda Jabar, Kombes Pol Yusri Yunus menuturkan: Dia orang sini, istrinya ada, anaknya dua sementara sedang hamil 7 bulan. Kesehariannya setelah keluar dari penjara memang *tertutup jarang berinteraksi. Sehari-hari menjual obat herbal. Dia guru ngaji di komunitasnya sendiri, salah satu murid ngajinya adalah pelaku bom di Kampung Melayu.” (06/06/2017) KOMPAS34:Hal.1-No.3

"Rusiono perwakilan keluarga pelaku mengatakan: Selama menikah, Puji mengikuti sikap suaminya. *Ia jarang bergaul dan menjadi pribadi yang lebih tertutup. Bahkan, dia mulai jarang berkunjung ke Banyuwangi termasuk saat lebaran. Puji pun jarang berkomunikasi intens dengan keluarganya." (Kompas.com, 14/05/2018) KOMPAS50:Hal.11-No.3

Dalam kasus ini, penggambaran latar belakang psikologis terhadap pelaku menciptakan stereotip bahwa orang-orang yang menyebabkan serangan teror cenderung memiliki kepribadian tidak toleran, temperatur amarah yang tinggi dan gampang merasa terganggu dengan hal-hal kecil. Dalam artikel yang paling banyak dijumpai, pelaku digambarkan sebagai orang yang menutup diri, tidak bersosial dengan lingkungannya.

Catatan Kepolisian. 'Catatan Kepolisian' juga ditemukan sebagai kategori dari 'pelaku' dalam artikel pemberitaan. Media berita online Kompas.com menggambarkan latar belakang kehidupan kriminal pelaku. Rincian laporan kriminal resmi dibuat oleh polisi untuk menggambarkan kegiatan ilegal yang dilakukan oleh pelaku *:

"Densus 88 Antiteror tidak asing dengan sosok Afif. Pada tahun 2010 lalu, *Densus 88 pernah menangkap Afif di Aceh atas perkara pelatihan perang dan kepemilikan senjata. Hakim memvonisnya hukuman tujuh tahun penjara." (Kompas.com, 15/01/2016) KOMPAS33:Hal.25-No.5

"Kabid Humas Polda Jabar, Kombes Pol Yusri Yunus menuturkan: Sebagai informasi * dia (Kiki) tahun 2016 kemarin baru keluar dari penjara kasus teroris di Cibiru, Bandung 2010. Sempat lima tahun di penjara. Di (kasus) Cibiru dia sebagai pembuat (bom) dan motivator." (Kompas.com, 06/06/2017) KOMPAS34:Hal.1-No.3

Media berita online Kompas.com menguraikan tindakan kriminal pelaku selama beberapa tahun terakhir hingga di mana pelaku melakukan serangannya. Media berita online Kompas. com juga sekaligus memberikan stereotip kepada pembaca bahwa pelaku selalu memiliki 
198 | Kajian Jurnalisme

Volume 05 Nomor 02 Tahun 2022

DOI: $10.24198 /$ jkj.v5i2.34429

kecenderungan melakukan kegiatan yang melanggar hukum. Hal ini mendorong audiens untuk berpikir bahwa orang-orang yang dicirikan terorisme yang menyebabkan teror penyerangan bom berasal dari latar belakang kriminal.

Tautan dengan ISIS. Pada banyak kesempatan, media berita cenderung enggan menyebut nama ISIS dalam artikel liputannya, namun hal ini tetap dilakukan media berita online Kompas.com untuk menarik hubungan antara pelaku dan kelompok Islam militan tersebut. Ini menunjukkan bahwa media berita online Kompas.com berusaha menyoroti hubungan antara pelaku dan ISIS *:

"Kepala Polri Jenderal Pol Badrodin Haiti menyebutkan bahwa satu dari *12 orang yang ditangkap Densus 88 Polri, menerima transfer dari Organisasi Islamic State of Iraq and Syria (ISIS). Mereka yang ditangkap diduga terlibat teror di kawasan Sarinah, Jalan Thamrin, Jakarta." (Kompas.com, 16/01/2016) KOMPAS26:Hal.18-No.4

"Kadiv Humas Mabes Polri Irjen Pol Setyo Warsito mengatakan: Ini ada kaitannya dengan serangan global, *kelompok yang menyerang beberapa tempat. Rekan-rekan tahu bahwa ada (ledakan bom di konser) Ariana Grande. Kita juga mendengar di negara tetangga kita, Filipina, ISIS menyerang kota Marawi." (Kompas.com, 25/05/2017) KOMPAS39:Hal.19-No.1

"Kapolri Jenderal Polisi Tito Karnavian mengatakan: Kelompok ini tidak lepas dari *kelompok bernama JAD-JAT, Jamaah Anshar Daulah-Jamaah Ansharut Tauhid yang merupakan pendukung utama ISIS." (Kompas.com, 13/05/2018) KOMPAS56:Hal.17No.8

Melalui hasil penggambaran tema dominan 'pelaku' dalam artikel berita, media berita online Kompas.com menciptakan stereotip teroris. Dari penggambaran 'pelaku', media berita online Kompas.com menumbuhkan sikap kognitif (pengetahuan) khalayak dengan menyebut pelaku sebagai 'pembom' dan 'penyerang bunuh diri' dan media memberikan gambaran kepada khalayak tentang aktivitas yang biasanya dilakukan pelaku teroris. Apalagi artikel berita yang disajikan justru memberikan informasi latar belakang psikologis dan catatan kepolisian pelaku, membangun stereotip masyarakat, orang-orang yang cenderung menyebabkan serangan teroris. Eratnya keterkaitan aksi eksterimisme pelaku dengan kelompok teroris menambah persepsi dan pemahaman (kognitif) masyarakat secara umum tentang ISIS. Dengan demikian, sikap kognitif yang dibangun oleh Kompas.com berisi kepercayaan seseorang mengenai objek. Seringkali apa yang telah dipercayai seseorang tersebut merupakan stereotip berdasarkan apa yang telah dilihat atau apa yang telah diketahui sehingga membentuk suatu ide atau gagasan mengenai sifat atau karakteristik umum suatu objek (Christopher, 2013).

Meskipun dalam banyak artikel berita menciptakan stereotip 'pelaku', media berita online Kompas.com tidak menghadirkan penggambaran dan ekspresi bentuk ketertarikan terhadap terorisme yang cenderung mendorong di antara anggota masyarakat untuk bergabung dengan kelompok teroris. Hasil penelitian menunjukkan bahwa media berita online Kompas.com hanya menyampaikan keterkaitan pelaku dengan ISIS dan beberapa kelompok teroris lainnya yang terafiliasi. Hanya saja, pemberitaan tentang serangan yang dilakukan teroris dalam artikel media berita online Kompas.com membantu penyebaran budaya teroris. Dapat diklaim bahwa media massa mengedarkan popularitas ISIS dan ideologinya (Djelantik, 2010), begitupun dengan media berita online Kompas.com.

\section{Tema 2: Solidaritas}

Ketika menganalisis data, 'solidaritas' ditemukan sebagai tema yang luas dengan penggambaran yang dikategorikan berdasarkan 'penggalangan dana', 'optimisme masyarakat', dan 'dukungan influencer' yang diulangi dengan sangat sering di artikel berita. Media berita online Kompas.com menekankan solidaritas masyarakat berupa tindakan saling mendukung 
terhadap para korban dan keluarganya. Meletakkan keyakinan bersama untuk menghentikan terorisme, hingga memunculkan gerakan tagar \#KamiTidakTakut pada terorisme pada berbagai media sosial. Semua ini diungkapkan dalam artikel berita online Kompas.com. Kehadiran solidaritas dalam artikel media berita online Kompas.com merangsang gagasan tentang dukungan dan persatuan masyarakat selama masa-masa sulit.

Penggalangan Dana. 'Penggalangan dana' didefinisikan sebagai kategori untuk solidaritas, karena media berita online Kompas.com menyajikan artikel berita tentang penggalangan dana untukmembantu keluarga korban yang meninggal dan mendukung pemulihan para korban dari cedera yang dialami. Media berita online Kompas.com menggambarkan penggalangan dana sebagai ekspresi solidaritas dan sekaligus mempromosikan ide dukungan masyarakat melalui kegiatan penggalangan dana *:

"Head of Fundraising Dompet Dhuafa, Boy Mareta, melalui keterangan pers: *Dana yang terkumpul akan kami salurkan untuk santunan keluarga, beasiswa anak almarhum, biaya sewa kontrakan, serta modal usaha agar mereka kembali mandiri." (Kompas.com, 21/01/2016) KOMPAS62:Hal.5-No.10

Selain itu, laporan media berita online Kompas.com juga menyoroti *sejumlah uang yang dikumpulkan dari aksi berdonasi tersebut. Liputan ini memberi pesan pentingnya aksi penggalangan dana dari masyarakat dan merepresentasikan dukungan kepada para korban. Dengan cara ini, media berita online Kompas.com menunjukkan kepada kita semua bahwa pentingnya untuk saling membantu korban akibat aksi kejam terorisme:

"Alissa dan Gusdurian menggalang donasi secara online melalui Kitabisa.com, dengan kampanye Santunan Korban Bom Surabaya \#KamiTidakTakut. Bantuan dari kita tidak bisa melerai seluruh duka, namun ini bukti persatuan dan kasih sayang. Donasi ini dibuka selama 31 hari kedepan. Hingga Senin (14/5/2018) pukul 10.15 WIB, telah *terkumpul Rp 4.426.202 yang berasal dari 15 donatur." (Kompas.com, 14/05/2018) KOMPAS117:Hal.15-No.5

"Mereka yang tergabung dalam Boston University Alumni Association Indonesia menginisiasi donasi para korban bom Surabaya, Simpati Untuk Korban Surabaya." Meski baru diinisiasi pada Minggu malam, campaign ini telah *mengumpulkan dana lebih dari Rp 19 juta." (Kompas.com, 14/05/2018) KOMPAS117:Hal.15-No.5

Dengan melaporkan artikel berita secara detail tentang penggalangan dana yang dilengkapi dengan ajakan dari tokoh populer untuk ikut serta berdonasi. Artikel berita ini menambahkan nilai inisiatif dan menumbuhkan simpatisme masyarakat bahwa penting untuk saling membantu dan mendukung para korban beserta keluarganya.

Optimisme Masyarakat. Saat memberitakan topik 'optimisme masayarakat' pasca serangan terorisme, media berita online Kompas.com mempromosikan nilai kepercayaan bersama untuk menjalani kehidupan normal meskipun terorisme telah mengancam. Keinginan dan kekuatan untuk terus menjalani kehidupan normal bersamaan dengan tekad untuk tidak menyerah pada terorisme adalah hal yang diucapkan berbagai anggota masyarakat di dalam artikel berita. Selain itu, media berita online Kompas.com juga menggambarkan sikap kolektif dan konstruktif masyarakat untuk terus melawan dan menghentikan terorisme. Kategori artikel pemberitaan 'optimisme masyarakat' mempromosikan nilai-nilai solidaritas, keyakinan, optimisme, dan kekuatan moral, sekaligus menyoroti dalam pemulihan masyarakat setelah aksi teror terjadi $*$ :

"Mereka bernyanyi dengan diterangi cahaya temaram dari lilin yang mereka nyalakan. Lagu yang mereka nyanyikan berjudul "Rayuan Pulau Kelapa" dan "Gugur Bunga". * Mereka membawa spanduk besar bertuliskan hastag \#KamiTidakTakut. Aksi tersebut mereka lakukan di depan logo Gedung Sarinah." (Kompas.com, 15/01/2016) KOMPAS77:Hal.21-No.1 
"Kekerasan tidak pernah menjadi jawaban. Inilah bentuk keyakinan kita bahwa kekerasan dan kekejaman tidak bisa dipraktikan untuk memaksakan kehendak, kepercayaan, ataupun ideologi apapun. *Mereka membawa spanduk bertuliskan Solidaritas Against Terrorism dan Kami Tidak Takut." (Kompas.com, 16/01/2016) KOMPAS74:Hal.17No.1

"Gereja menghimbau umat Katolik agar tetap tenang dan tidak takut terhadap aksi teror. Tetaplah setia berbuat baik penuh kasih kepada siapa pun, sesuai dengan nilai Kristiani yang diajarkan Tuhan Yesus. Mari memberikan pengampunan yang tulus. Karena *pengampunan yang tulus adalah pintu yang terbuka untuk masa depan yang lebih bermartabat bagi bangsa Indonesia." (Kompas.com, 14/05/2018) KOMPAS109:Hal10.No.4

Serangan terorisme mungkin telah menguji banyak masyarakat Indonesia. Kendati demikian, media berita online Kompas.com dalam artikel beritanya menghadirkan harapan dan keyakinan akan kemampuan masyarakat untuk melanjutkan kehidupan sehari-hari sebelum adanya teror. Media berita online Kompas.com menggunakan berbagai kutipan dari anggota masyarakat melalui media sosial untuk memperlihatkan masyarakat memiliki optimisme kuat untuk bersatu meredam ketakutan. Artikel liputan ini memperkuat citra *solidaritas masyarakat dan pandangan positif untuk saling menjaga sesama:

"Selamat pagi, Jakarta! Joko Anwar@ @jokoanwar" (Kompas.com, 25/05/2017) KOMPAS99:Hal.17-No.2

"Turut berduka u/ korban ledakan Kp Melayu. Tuhan akan menjaga kita. Dan *kita yg akan saling menjaga sesama. \#PrayFor Jakarta \#KamiTidakTakut, Twitter @ Cadhekbkl." (Kompas.com, 24/05/2017) KOMPAS104:Hal.20-No.8

"Manchester, Marawi, Bangkok, and now in Kampung Melayu :'(( *Send our love \& pray for all victims. Asrafil (@asrfll)." (Kompas.com, 24/05/2017) KOMPAS104:Hal.20No.8

"Kota Pahlawan selalu mengajarkan, bahwa *WANI adalah pedoman. \#KamiTidakTakut \#StayStrongSurabaya Doa dari kami untuk teman-teman di Surabaya. \#PrayForSurabaya. Melalui twitter Persib Bandung." (Kompas.com, 13/05/2018) KOMPAS128:Hal.21No.1

Dukungan dari Influencer. Tokoh-tokoh penting dan sederetan artis nasional digambarkan menunjukkan bantuan dan dukungan mereka secara langsung maupun melalui media sosial kepada para korban dan keluarga. Upaya publikasi media berita online Kompas.com tentang peristiwa ini dalam artikel berita dapat memengaruhi masyarakat secara luas untuk mengikuti sikap yang ditunjukkan dalam membantu satu sama lain *:

"Beberapa *tokoh ikut hadir memberi dukungannya, antara lain Erry Riyana Hardjapamekas, Todung Mulya Lubis, Komaruddin Hidayat, Frans Magnis Suseno, Chandra M Hamzah, HS Dillon, Bivitri Susanti, Eryanto Nugroho, dan M Nur Solikhin. Erry sebagai mantan Wakil Ketua KPK menuturkan: Kami mengecam keras segala tindakan terorisme, dengan alih apa pun, yang mengganggu keamanan dan menebar ketakutan di masyarakat." (Kompas.com, 15/01/2016) KOMPAS97:Hal.16-No.5

"Turut berduka untuk para korban ledakan bom Kampung Melayu. \#PrayForJakarta Everyone, please stay safe! \#PrayForJakarta *Raisa Andriana @raisa6690" (Kompas. com, 25/05/2017) KOMPAS99:Hal.17-No.2

"Doa dan dukungan moral untuk para korban dan keluarga yang ditinggalkan. \#PrayForJakarta \#PrayForHumanity \#SatuIndonesia *@darius_sinathrya." (Kompas. com, 25/05/2017) KOMPAS97:Hal.16-No.5

"Peristiwa pemboman beberapa gereja di Surabaya turut menjadi perhatian pembalap MotoGP dari tim Ducati, *Jorge Lorenzo. Senin (14/5/2018), pembalap bernomor 99 ini tampak mengunggah kalimat "Pray for \#Indonesia" di akun twitter, @lorenzo99." (Kompas.com, 14/05/2018) KOMPAS112:Hal.12-No.4 
Dalam hal solidaritas, media berita online Kompas.com melaporkan bahwa komunitas dunia juga mendukung dan berdiri bersama. Negara-negara di seluruh dunia turut berbelasungkawa dan menawarkan bantuannya. Informasi tersebut juga disajikan sebagai artikel berita sebagai tanda solidaritas. Sembari memperlihatkan reaksi negara-negara asing, media berita online menyajikan berita terorisme sebagai sebuah masalah global:

"Menteri Polhukam, Luhut Binsar mengatakan: Negara-negara ini nawarin, tetapi kita sampai sekarang masih merasa cukup dengan kemampuan kita." Sejumlah negara yang menawarkan bantuan, *antara lain: Amerika Serikat, Australia, Singapura, dan Malaysia". (Kompas.com, 16/01/2016) KOMPAS75:Hal.20-No.1

“*Walid Abdel Rahman Al Hadid, Dubes Jordania: Raja mengecam serangan-serangan teroris yang mengguncang Jakarta kemarin. Raja juga menegaskan bahwa Jordania berdiri bersama dengan Indonesia untuk memerangi aksi-aksi teroris seperti ini." (Kompas.com, 16/01/2016) KOMPAS73:Hal.16-No.8

“*Presiden Singapura Tony Tan Keng Yam dan PM Lee Hsieen Loong langsung mengirimkan surat belasungkawa kepada Presiden Joko Widodo. Keduanya menyampaikan belasungkawa untuk keluarga korban tewas dan mengecam perilaku keji pelaku bom Kampung Melayu." (Kompas.com, 26/05/2017) KOMPAS89:Hal.9No.6

Tema dominan 'solidaritas' pada penelitian ini juga menemukan bahwa media berita online Kompas.com sangat memperhatikan solidaritas masyarakat. Artikel berita yang melaporkan solidaritas antar masyarakat menambahkan bukti kuat yang menekankan tentang betapa pentingnya mempersatukan masyarakat pasca serangan teroris. Penelitian ini mengungkapkan bahwa media berita online Kompas.com sangat sering menggambarkan bagaimana solidaritas masyarakat yang terkena dampak aksi terorisme dengan mengekspresikan keyakinan serta optimisme bersama untuk melawan terorisme. Temuan ini turut memperkenalkan peran baru media berita online sebagai penggerak solidaritas dalam pemberitaan serangan teroris. Dengan membangun nilai artikel berita untuk mempromosikan solidaritas di antara masyarakat, lebih lanjut temuan mengemukakan bahwa tidak hanya pemberitaan konsep audio visual yang dapat mendorong solidaritas dan empati masyarakat, tetapi juga konten tertulis dari artikel media berita online.

Temuan tema dominan 'solidaritas' di tengah masyarakat yang juga kerap ditunjukkan setiap kali peristiwa serangan teroris terjadi oleh media berita online Kompas.com yakni aksi penggalangan dana untuk keluarga korban. Bersamaan dengan itu, media berita online Kompas. com menyertakan kutipan tokoh penting dan artis dalam artikel beritanya. Menggunakan kutipan tokoh-tokoh berpengaruh tersebut memungkinkan media berita online Kompas.com untuk memengaruhi masyarakat agar mengikuti teladan mereka dalam membantu satu sama lain. Dengan menonjolkan isu mengenai solidaritas dalam pemberitaannya, media berita online Kompas.com menjadikan isu solidaritas sebagai agenda media dalam setiap pemberitaannya mengenai teroris.

Media massa merupakan media yang memiliki pengaruh yang kuat dan masif pada masyarakat. Teori Agenda Setting mengasumsikan bahwa ketika agenda media kemudian telah diterima oleh masyarakat sebagai agenda publik, maka publik kemudian akan memiliki respon aktif terhadap agenda tersebut. Dalam hal ini, ketika kemudian agenda media mengenai isu solidaritas dalam pemberitaan teorisme ditonjolkan dan menjadi agenda publik, maka kemudian muncul aksi-aksi penggalangan dana sosial bagi para korban serangan teroris (Juditha, 2019).

\section{Tema 3: Korban}

Representasi 'korban' serangan terorisme diangkat sebagai subjek dalam tema yang luas dalam artikel berita. Media berita online Kompas.com menampilkan korban dari 
202 | Kajian Jurnalisme

Volume 05 Nomor 02 Tahun 2022

DOI: $10.24198 / \mathrm{jkj} . v 5 \mathrm{i} 2.34429$

beberapa kategori yakni, upacara pemakaman, kehilangan keluarga, dan penghormatan bagi korban. Kategori-kategori tersebut memuat berbagai sudut pandang korban, di antaranya memperlihatkan bakat yang dimilki, kepribadian korban, anggota keluarga yang ditinggalkan dan pentingnya korban bagi anggota keluarga, hingga bahkan pemakaman korban. Selain itu, ingatan dan perasaan sentimental tentang para korban juga disajikan oleh media berita online Kompas.com. Dengan cara ini, media berita online Kompas.com memediasi berbagai macam emosi yang muncul di kalangan masyarakat akibat serangan terorisme. 'Upacara pemakaman', 'kehilangan keluarga', dan 'penghormatan bagi korban' ditampilkan sebagai sub-tema:

Upacara Pemakaman. 'Upacara pemakaman' ditemukan sebagai kategori untuk 'korban'. Media berita online Kompas.com menyediakan bagi pembacanya dengan deskripsi yang luas mengenai upacara pemakaman korban. Menariknya, meski proses pemakaman umumnya peristiwa yang menyedihkan bagi keluarga dan kerabat korban, media berita online Kompas. com tetap meliputnya dan menjadikannya artikel berita dengan penuh rasa emosional *:

“*Jeritan isak tangis mewarnai prosesi pemakaman Rais. Rahmat adik korban menangis histeris dan terjatuh lemas. Dia dipapah keluar dari kerumunan keluarga dan kerabat yang mengiringi pemakaman Rais. Tak lama kemudian ibunya jatuh pingsan bertepatan setelah jenazah anaknya dimasukkan ke liang lahat, dia terlihat lemas dan pingsan." (Kompas.com, 18/01/2016) KOMPAS135:Hal.14-No.2

"Tembakan ke udara dilakukan pertanda pemakaman dimulai. Suasana di pemakaman tak luput dari haru. Saat jenazah dikeluarkan dari peti, kerabat dan keluarga tak bisa tahan isak tangis untuk melihat jenazah yang terakhir kalinya. *Saat petugas makam menutup liang kubur, kembali isak tangis keluarga dan kerabat tak dapat dibendung lagi." (Kompas.com, 25/05/2017) KOMPAS156:Hal.14-No.8

"Bahkan *Segijo, sang ayah, sempat pingsan saat peti mati mulai dimasukkan ke liang lahat. Sontak, para pengantar jenazah yang berada di samping kanan dan kiri Soegijo memegangi erat dan membopong tubuh Soegijo ke mobil pengantar keluarga." (Kompas. com, 23/05/2018) KOMPAS170:Hal.1-No.5

Media berita online Kompas.com memilih untuk menggambarkan suasana pemakaman korban dengan cara menyampaikan perasaan emosional mendalam dari keluarga dan kerabat korban kepada pembaca melalui deskripsi artikel.

Kehilangan Keluarga. 'Kehilangan keluarga' telah menjadi kategori tema 'korban' yang paling umum dalam media berita online Kompas.com saat meliput korban dari serangan teroris. Banyak kutipan dari hasil wawancara anggota keluarga korban yang meninggal yang telah digambarkan dalam artikel berita. Secara keseluruhan menyoroti perasaan kehilangan, kehancuran, dan penderitaan moral yang dialami oleh keluarga korban *:

"Ibunda korban mengatakan: *Rais yang merupakan tulang punggung keluarga meninggalkan seorang istri, Laili Herlinda, dan dua anak yang masih sangat kecil, yakni Siti Ataya Ramadhani (5) dan Keyanu Aprilia (2)." (Kompas.com, 18/01/2016) KOMPAS134:Hal.13-No.6

“*Adiknya di surga, kebanggan kita. Sudah jalannya, jalan yang terbaik, ujar salah seorang kerabat menenangkan ibu dan kakak Ridho." (Kompas.com, 25/05/2017) KOMPAS157:Hal.15-No.2

“*Aaron memang tanya terus ayahnya di mana. Kenapa ayahnya ada di dalam peti?

Kami tidak ingin membohongi dia, keluarga menceritakan ayahnya sudah bersama

Tuhan Yesus, dan menjadi malaikat. Ayah akan selalu melindungi ibu, Aaron, juga adiknya mesti tidak terlihat, Galih, adik korban.” (Kompas.com, 22/05/2018) KOMPAS173:Hal.2-No.1

Pentingnya sosok korban bagi anggota keluarga dan kerabat juga digambarkan oleh media berita online Kompas.com dalam artikelnya. Ini menekankan peran yang begitu penting yang dimainkan para korban dalam keluarganya *: 
Volume 05 Nomor 02 Tahun 2022

DOI: $10.24198 / j k j . v 5 i 2.34429$

"Luthfi keponakan korban mengatakan: *Sugito merupakan sosok penopang ekonomi keluarga. Hanya beliau saat itu berada pada waktu yang tidak tepat. Kami kehilangan beliau." (Kompas.com, 22/01/2016) KOMPAS133:Hal.5-No.10

"Taufan anak saya, *Taufan tonggak saya. Taufan.. Taufan tuh nggak ada. Nggak pernah (bicara) enggak, selalu iya, ujar Asijah Ibunda korban." (Kompas.com, 25/05/2017) KOMPAS146:Hal.12-No.1

"Sumijah, sang nenek, mengatakan, Daniel memang bertanggung jawab untuk mengatur parkiran kendaraan setiap Minggu pagi. *Dia mengemban tugas itu setelah sang kakek yang sebelumnya bertugas yang sama meninggal dunia. "dia menggantikan kakeknya yang jaga. Kakeknya dipanggil Tuhan, dia yang gantiin." (Kompas.com, 18/05/2018) KOMPAS175:Hal.3-No.2

Penghormatan bagi Korban. Saat memberitakan berita mengenai serangan teroris dan korbannya, media berita online Kompas.com menunjukkan kecenderungan untuk mengutip pernyataan tentang korban yang mempunyai peran dalam keluarga dan kepribadian yang unik semasa hidupnya. *Kepribadian korban biasanya digambarkan sebagai sosok yang bertanggung jawab, baik, religius, rajin, dan penyayang. Seringkali korban dianggap penting bagi keluarga dan kerabat. Secara tidak disadari, hal ini menambah signifikan kerugian bagi keluarga korban dan yang dialami masyarakat sebagai akibat dari peristiwa serangan teroris:

"Paman korban mengatakan: Dia anak yang rajin. Sehari-hari, *dia suka mengantar keluarganya pergi. Dia adalah salah satu anggota karang taruna. Rico dua bersaudara, lulusan SMK Angkasa, Halim, Jakarta Timur." (Kompas.com, 16/01/2016) KOMPAS136:Hal.16-No.6

"Ya, *dia selama ini cerita kalau dia bangga menjadi polisi yang bisa bekerja dekat dengan masyarkat. Dedikasi tinggi ini ditunjukkan dengan dia malam itu jam 21.00 masih ada di lapangan. Loyalitas di luar batas kewajiban ini, menjadi dasar Polri menaikkan pangkat Gilang menjadi Briptu Anumerta." (Kompas.com, 25/05/2017) KOMPAS159:Hal.15-No.7

"(Almarhum)* baik dan tanggung jawab, ujar Denanda adik bungsu almarhum Briptu Taufan Tsunami.” (Kompas.com, 25/05/2017) KOMPAS152:Hal.13-No.8

"Beliau tidak sempat menikah, jadi aktivitasnya tidak terlalu banyak. *Beliau ini sangat rajin ibadah dan sering ke gereja. Beliau juga sangat perhatian kepada ponakan-ponakannya. Ujar Budi, keluarga korban." (Kompas.com, 17/05/2018) KOMPAS176:Hal.3-No.8

\section{Tema 4: Kekerasan}

'Kekerasan' ditemukan sebagai satu lagi tema yang mendominasi pemberitaan tentang serangan terorisme di media berita online Kompas.com. Penggambaran berbagai 'cedera' dan 'deskripsi adegan' dimunculkan sebagai sub-tema, mendukung adanya efek kekerasan dari serangan teroris yang terjadi. Sedangkan sub-tema 'peningkatan tingkat ancaman' ditemukan sebagai identifikasi akan kemungkinan terjadinya lebih banyak serangan teroris:

Cedera. Liputan berita serangan teroris yag dilaporkan media berita online Kompas.com menggambarkan 'cedera' dan trauma fisik yang dialami para korban akibat peristiwa tersebut. Dengan cara ini, media berita online Kompas.com mengintensifkan persepsi negatif masyarakat mengenai kekerasan. Peristiwa serangan terorisme yang digambarkan dalam artikel media berita online Kompas.com menyampaikan gambaran kekerasan yang mengerikan:

"Novi yang menjadi korban selamat menyampaikan: Buat gerakin tangan saja susah, sakit. Ini 12 jahitan sampai ke dalam-dalamnya. Kata dokter, biasanya, orang dijahit di kulit, saya dijahit di daging dua lapis." (Kompas, 15/01/2016) KOMPAS209:Hal.24No.9

"Menteri Hukum dan HAM Yasonna Laoly menuturkan: Saya lihat kondisinya cukup mengenaskan, sekujur tubuhnya banyak bekas serpihan-serpihan bom. Yang paling 
204 | Kajian Jurnalisme

Volume 05 Nomor 02 Tahun 2022

DOI: $10.24198 /$ jkj.v5i2.34429

parah mata sebelah kiri, rusak total, kemungkinan tidak bisa melihat." (Kompas.com, 30/05/2017) KOMPAS211:Hal.2-No.4

"Korban mengalami patah tulang dibagian dadanya. Sementara bagian bawah tubuhnya hancur akibat ledakan bom.” (Kompas.com, 14/05/2018) KOMPAS222:Hal.9-No.3

Lebih jauh lagi, media berita online Kompas.com menggambarkan perjuangan yang harus diatasi oleh korban yang selamat. Korban tidak hanya luka fisik, tapi juga menerima dampak psikologis dari efek kejam serangan terorisme:

"Kalau kondisinya sudah baikan, hanya kuping kiri yang masih berdengung. Novi juga enggan keluar rumah karena trauma. Jalan pun harus dipegang seperti orang pincang. Tidurnya juga harus ditemani dengan lampu menyala." (Kompas.com, 19/01/2016) KOMPAS196:Hal.10-No.8

"Satu anak perempuan terduga teroris, AAP(7) disebut masih mengalami trauma psikologi pasca-ledakan bom di depan Mapolrestabes Surabaya. Saat ini Ais hanya ngomong sama suster penjaganya saja." (Kompas.com, 16/05/2018) KOMPAS219:Hal.5-No.6

Deskripsi Adegan. 'Deskripsi adegan' tentang lokasi penyerangan menjadi topik yang sangat hangat dalam artikel media berita online Kompas.com mengenai serangan terorisme. Dengan demikian, penggambaran adegan tersebut muncul sebagai sub-tema dalam 'kekerasan'. Kesan berbagai saksi dikutip untuk mengungkapkan kengerian dan mencekamnya selama adegan tersebut. Media berita online Kompas.com menunjukan kepada masyarakat betapa kejamnya pelaku serangan teroris:

"Setelah ledakan yang kedua, ira menyaksikan, pos polisi sudah hancur, dan tiga jasad manusia sudah tergeletak di sekitarnya. Ira mengaku dapat memastikan ketiganya sudah tewas dari darah yang tercecer di sekitarnya. Salah satu mayat, perutnya mengeluarkan asap. Saat itu, saya menyimpulkan, itu pasti bom bunuh diri." (kompas.com, 15/01/2016) KOMPAS206:Hal.24-No.3

"Ledakan pertama oleh Ichwan, dia hanya luka bagian belakang. Second service oleh Ahmad terjadi 4 menit setelahnya. Setelah meledak, badannya hancur, kepala terlempar sampai masuk halte busway, bagian tubuh lainnya terpecah.” (Kompas.com, 26/05/2017) KOMPAS213:Hal.6-No.3

"Mulyanto, juru parkir gereja, mengatakan, dia dan Yesayas (satpam gereja) masih sempat bercanda sambil nyemil makanan di lokasi (sebelum ledakan). Dia kemudian keluar dan setelah kejadian itu, dia melihat Yesayas terkapar. Wajahnya luka berdarahdarah. Badannya juga luka-luka. Dia teriak-teriak minta tolong." (Kompas.com, 13/05/2018) KOMPAS227:Hal.19-No.10

Selain itu, media berita online Kompas.com juga memilih untuk mendeskripsikan secara detail betapa kejamnya serangan tersebut. Memperkuatnya dengan citra horor dengan mengutip keterangan saksi. Selain kekerasan, media berita online juga menyoroti kepanikan yang terjadi selama di lokasi terjadinya serangan:

"Sigit salah satu pengunjung mengatakan: Aku langsung panik, aku sudah enggak bisa dengar pengunjung lain lagi, bunyi dentuman bikin kupingku berdengung karena dekat banget ledakannya. Saat itu kondisi sudah luluh lantak. Sampai di parkiran, sudah ada bom kedua yang sudah meledak." (Kompas.com, 15/01/2016) KOMPAS208:Hal.24No.8

"Ledakan pertama pukul 21.00, saya langsung ke TKP. Saat berdiri sekitar 1 meter dari TKP, terjadi ledakan kedua. Polisi yang berada di TKP berhamburan karena takut ledakan ketiga." (Kompas.com, 24/05/2017) KOMPAS217:Hal.20-No.9

"Tidak lama kemudian, suara jeritan dan permintaan tolong datang dari arah gereja. Dia pun langsung lari menuju ke gereja. Saat itu, menurut dia, suasana kacau. Kaca berserakan dan pos satpam yang ada di gereja hancur. Ada bapak-bapak yang lari membopong anaknya. Ujar Firman Ketua RT/RW 5 Baratajaya". (Kompas.com, 13/05/2018) KOMPAS229:Hal.24-No.2 
Peningkatan Tingkat Ancaman. Media berita online menggambarkan prediksi peningkatan ancaman serangan susulan teroris di Indonesia. Laporan artikel ini juga menginformasikan pembaca tentang resiko terjadinya lebih banyak serangan teroris:

"Pengamat terorisme CIIA Harits Abu Buya mengatakan: Aksi kemarin sangat signifikan untuk sel lain. Beredar foto Afif itu tampil keren, tenang, sangat heroik bagi mereka, sangat inspiratif. Dikhawatirkan aksi ini dikloning." (Kompas.com, 16/01/2016) KOMPAS201:Hal.17-No.9

"Indonesia adalah negara mayoritas Muslim. Negara kepulauan berpenduduk 260 juta tersebut telah menyaksikan kebangkitan militansi Islam dalam beberapa tahun terakhir, namun skala serangan di Surabaya telah menimbulkan kekhawatiran baru tentang potensi jaringan jihadis, tulis BBC." (Kompas.com, 15/05`/2018) KOMPAS221:Hal.8-No.8

"Pengamat terorisme dari UI mengatakan: Kalau dilakukan perempuan dan anak-anak lebih sulit diidentifikasi, tidak terlalu curiga, apalagi satu keluarga." (Kompas.com, 15/05/2018) KOMPAS220:Hal.8-No.5

Oleh sebab itu, media berita online Kompas.com sangat sering menampilkan kekerasan dalam pemberitaannya tentang aksi teror. Melalui cara ini, media berita online Kompas.com menstimulasi gagasan tentang betapa brutalnya terorisme bisa terjadi, bisa menghadirkan ancaman bahaya sekaligus kepanikan sebagai konsekuensi dari serangannya.

Pada temuan tema dominan 'korban' dan 'kekerasan' dalam laporan artikel media berita online Kompas.com. Berdasarkan analisis yang telah dilakukan, hasil penelitian menunjukkan bahwa isi pemberitaan tentang 'korban' dan 'kekerasan' mewakili emosi yang beragam di tengah masyarakat. Melalui penggambaran para korban, media berita online Kompas.com khusus menekankan rasa sakit dan penderitaan dari kejauhan yang dikarenakan oleh kehilangan anggota keluarga, kerabat dan teman sebagai akibat dari serangan teroris. Demikian pula halnya dengan 'kekerasan' yang digambarkan melalui deskripsi adegan, penggambaran adegan yang penuh dengan kekerasan juga sangat sering ditampilkan dalam pelaporan berita yang menyampaikan kepanikan dan ketakutan.

Hasil analisis penelitian dari tema dominan 'korban' dan 'kekerasan' mengungkapkan bahwa media berita online Kompas.com memilih mengutip saksi-saksi selamat dari serangan teroris, orang-orang terdekat dengan tempat peristiwa disaat penyerangan teroris terjadi, korban luka-luka, keluarga dan kerabat, kekasih dan teman-teman korban, daripada menampilkan konten deskriptif. Oleh karena itu, cara media berita online Kompas.com dalam melaporkan serangan teroris dapat dianggap spekulatif. Sebab, artikel berita ini menyuguhkan laporan berita yang mengeksploitasi kesedihan dan histeria keluarga korban secara berulang dan berlebihan. Jenis liputan berita ini membuat konten lebih emosional, terus terang, dan kredibel bagi publik (Suyanto, 2012), yang akibatnya memperkuat kekuatan media berita online Kompas.com untuk memengaruhi pembacanya saat melaporkan serangan teroris.

Pengaruh yang dihasilkan media berita online Kompas.com saat melaporkan tema dominan 'korban' dan 'kekerasan' dari serangan teroris memperkuat kehadiran efek serangan tersebut di tengah-tengah masyarakat. Laporan berita yang terdiri dari kesan negatif saksi, penggambaran momen-momen kekerasan dan representasi kerugian yang dialami keluarga dan kerabat korban pasca serangan dapat memberikan pengaruh emosional yang negatif bagi masyarakat (Azaria \& Nasution, 2019). Seperti yang telah disampaikan sebelumnya, media berita online Kompas. com menyebarkan berbagai emosi, seperti rasa sakit, penderitaan, panik dan ketakutan melalui pemberitaannya. Dengan demikian, dapat dikatakan bahwa setelah banyaknya korban yang berjatuhan dan kerusakan fisik yang diakibatkan dalam penyerangan tersebut, media berita online Kompas.com melampiaskan berbagai rasa emosional ketika memberitakan berita terkait dengan serangan teroris tersebut. Representasi aspek negatif dari serangan teroris di depan umum menciptakan iklim teror di dalam masyarakat yang meningkatkan ketakutan 
206 | Kajian Jurnalisme

Volume 05 Nomor 02 Tahun 2022

DOI: $10.24198 /$ jkj.v5i2.34429

terhadap peristiwa tersebut. Oleh karena itu, dengan menyampaikan tema-tema tersebut dalam pemberitaan, media berita online Kompas.com dapat memperpanjang efek kejadian yang sebenarnya.

Berdasarkan agenda media yang ditonjolkan yaitu isu 'korban' dan 'kekerasan' dari artikel berita di atas yang disajikan, media berita online Kompas.com dalam artikel berita serangan terorismenya mencapai pengaruhnya pada sikap afektif (perasaan) terhadap audiens. Media berita online Kompas.com mengirimkan pesan emosi tersebut kepada audiens, sehingga menciptakan pengaruh afektif mengenai perasaan emosional dan rasa takut. Maka dari itu, media mengirimkan pesan penggambaran kekerasan yang dialami oleh korban dalam pemberitaan media berita online Kompas.com tentang serangan teroris sehingga menjadi agenda publik yang dilihat sebagai perantara rasa sakit, penderitaan, ketakutan dan kepanikan di kalangan masyarakat (Mcquail, 2011). Berdasarkan itu semua dapat dikatakan bahwa media berita online Kompas.com dapat membantu tercapainya tujuan aksi terorisme (Purwawidada, 2014).

Setelah menetapkan hasil temuan dari beberapa data yang disajikan, hasil penelitian menunjukkan bahwa media berita online Kompas.com memberitakan isu tertentu, lalu memperkuatnya melalui liputan yang luas. Hasil analisis tematik menemukan bahwa 'pelaku', 'solidaritas', 'korban', dan 'kekerasan' menjadi tema dominan dalam liputan serangan teroris yang terjadi dalam lima tahun terakhir di Indonesia. Topik-topik yang berlaku dalam artikel media berita online Kompas.com menunjukkan bahwa media cenderung menampilkan fenomena yang terjadi dari berbagai sudut dan menyoroti subjek tertentu.

\section{SIMPULAN}

Berdasarkan analisis isi dari artikel Kompas.com mengenai liputan berita serangan terorisme di Indonesia dalam kurun waktu 2016-2020 yang bertumpu pada teori Agenda Setting, penelitian ini menemukan pola pemberitaan yang dimainkan media berita online Kompas.com dalam melaporkan serangan teroris. Penelitian menunjukkan bahwa media berita online Kompas.com sangat memperhatikan efek emosional dari serangan teroris terhadap audiens, yang akibatnya memediasi lebih banyak emosi pada masyarakat. Selain itu, fokus pada kekerasan dalam pemberitaan dapat menebar ketakutan dan kepanikan di kalangan publik. Menariknya lagi bahwa media berita online Kompas.com berperan sebagai penggerak solidaritas dan bahkan dapat mendorong masyarakat untuk mendukung para korban dan keluarganya baik secara finansial maupun psikologis.

Penelitian mengungkapkan bahwa liputan berita serangan teroris di Indonesia mencakup berbagai fakta tentang pelaku, solidaritas, korban dan kekerasan yang mengandung berbagai kutipan emosional tentang penderitaan pasca serangan terorisme. Di satu sisi, Indonesia sebagai negara demokrasi, jurnalis memiliki hak untuk menyampaikan laporan serangan teroris secara mendalam dan publik memiliki hak untuk mengetahui apa yang sedang terjadi. Namun pada sisi yang lain, liputan berita yang mendalam tentang serangan teroris dapat menempatkan masyarakat pada berbagai resiko. Oleh sebab itu, penelitian ini penting adanya dengan mengetahui peran yang dimainkan oleh media berita online saat melaporkan serangan teroris, yang akan membantu jurnalis untuk memahami efek penting saat melaporkan peristiwa tersebut.

\section{DAFTAR PUSTAKA}

Azaria, T., \& Nasution, B. (2019). Objektivitas pemberitaan kasus penyerangan terduga terorisme markas kepolisian daerah (MAPOLDA) Riau di tribunpekanbaru.com. JOM Fisip, 6(1), 1-10. Diakses dari https://jom.unri.ac.id/index.php/JOMFSIP/article/ 
Volume 05 Nomor 02 Tahun 2022

DOI: $10.24198 / j k j . v 5 i 2.34429$

view/22853

Bakti, A. S. (2014). Darurat terorisme: peran BNPT, pencegahan, perlindungan dan deradikalisasi. Jakarta: Daulat Press.

Braun, V., \& Clarke, V. (2006). Using thematic analysis in psychology. Qualitative Research in Psychology, 3(2), 77-101. https://doi.org/10.1191/1478088706qp063oa

Budiasih, I. G. A. N. (2014). Metode grounded theory dalam riset kualitatif. Jurnal Ilmiah Akuntansi Dan Bisnis, 9(1), 19-27. Diakses dari https://ojs.unud.ac.id/index.php/jiab/ article/view/10869

Christopher. (2013). Sikap masyarakat Surabaya dalam menonton video klip Psy-Gangnam Style di Youtube. Jurnal E-Komunikasi, 1(3), 288-297. Diakses dari https://publication. petra.ac.id/index.php/ilmu-komunikasi/article/view/942

Dermawan, W., Affandi, R. N., \& Alam, G. N. (2018). Pencegahan radikalisasi melalui pengembangan demokrasi islamik di Kecamatan Tempuran Kabupaten Karawang. Kumawula: Jurnal Pengabdian Kepada Masyarakat, 1(2), 75-89. https://doi. org/10.24198/kumawula.v1i2.19612

Dewan Pers. (2017). Kredibilitas media dan reputasi bangsa. Etika. Diakses dari https:// dewanpers.or.id/assets/ebook/buletin/470-JUNI 2017.pdf

Djelantik, S. (2010). Terorisme: tinjauan psiko-politis, peran media, kemiskinan, dan keamanan nasional (1st ed.). Jakarta: Yayasan Pustaka Obor Indonesia.

Effendy, O. U. (2009). Ilmu komunikasi: Teori dan praktek. Bandung: Remaja Rosda Karya.

Farisa, F. C. (2021, March 30). 522 aksi teror terjadi sejak tahun 2000, terbanyak di era SBY. Kompas.Com.Diakses darihttps://nasional.kompas.com/read/2021/03/30/15460211/552aksi-teror-terjadi-sejak-tahun-2000-terbanyak-ada-di-era-sby?page=all

Handayani, F. P., \& Merdekawati, I. (2019). Kebijakan penggunaan media online website Kompas TV dan Youtube untuk menyalurkan konten "eksklusif digital" Kompas TV. Jurnal Kajian Jurnalisme, 2(2), 198-211. https://doi.org/10.24198/jkj.v2i2.21361

Heriyanto. (2018). Thematic analysis sebagai metode menganalisa data untuk penelitian kualitatif. Anuva: Jurnal Kajian Budaya, Perpustakaan, Dan Informasi, 2(3), 317-324. https://doi.org/10.14710/anuva.2.3.317-324

Jonathan, A. C., \& Herdiana, I. (2020). Coping stress pascacerai: kajian kualitatif pada ibu tunggal. INSAN Jurnal Psikologi Dan Kesehatan Mental, 5(1), 71-87. https://doi. org/10.20473/jpkm.v5i12020.71-87

Juditha, C. (2019). Agenda setting penyebaran hoaks di media sosial. Jurnal Penelitian Komunikasi, 22(2), 155-168. https://doi.org/10.20422/jpk.v22i2.669

Junaedi, F. (2017). Relasi terorisme dan media. Jurnal ASPIKOM, 1(1), 15-25. https://doi. org/10.24329/aspikom.v1il.5

Martha, T., \& Irwansyah. (2017). Peran agenda setting media massa dalam kebijakan penetapan Harga Eceran Tertinggi (HET) beras oleh pemerintah. JIPSi: Jurnal Ilmu Politik Dan Komunikasi, VII(2), 227-236. Diakses dari https://ojs.unikom.ac.id/index.php/jipsi/ article/view/549

Mcquail, D. (2011). Teori komunikasi massa McQuail (McQuail mass communication theory) (6th ed.). Jakarta: Salemba Humanika.

Musyaffa. (2017). Konstruksi pemberitaan media online indonesia terhadap ISIS (analisis framing Kompas.com, Okezone.com, Tempo.co , dan Republika.co.id) (Universitas Islam Negeri Syarif Hidayatullah Jakarta). Universitas Islam Negeri Syarif Hidayatullah Jakarta. Diakses dari https://repository.uinjkt.ac.id/dspace/handle/123456789/38300

Pabyantara, D., Wibowo, P., \& Zamzamy, A. (2018). Terorisme di Indonesia: antara kepentingan 
208 | Kajian Jurnalisme

Volume 05 Nomor 02 Tahun 2022

DOI: $10.24198 / \mathrm{jkj} . \mathrm{v} 5 \mathrm{i} 2.34429$

politik negara dan permasalahan ontologis. Global \& Policy, 6(2), 141-152. Diakses dari http://ejournal.upnjatim.ac.id/index.php/jgp/article/view/1822

Purwawidada, F. (2014). Jaringan baru teroris Solo (E. Saputra, Ed.). Jakarta: Kepustakaan Populer Gramedia.

Rahmat, J. (1993). Psikologi Komunikasi. Bandung: Remaja Rosda Karya.

Roy Morgan. (2018). Detikcom, kompas.com \& liputan6 are Indonesia's leading news websites.

Diakses dari roymorgan.com website: http://www.roymorgan.com/findings/7622-top10-indonesian-news-websites-march-2018-201806172227

Suyanto. (2012). Representasi nilai berita feature pada remaja di surat kabar. Jurnal Ilmu Komunikasi, 1(1), 26-30. Diakses dari https://jkms.ejournal.unri.ac.id/index.php/JKMS/ article/view/606/0

Windiani, R. (2018). Peran Indonesia Dalam Memerangi Terorisme. Jurnal Ilmu Sosial, 16(2), 135. https://doi.org/10.14710/jis.16.2.2017.135-152 